\title{
Merizocotyle euzeti sp. n. (Monogenea: Monocotylidae) from the nasal tissue of three deep sea skates (Rajidae) in the southwestern Atlantic Ocean
}

\author{
Manuel M. Irigoitia ${ }^{1,3,4}$, Delfina M. P. Cantatore ${ }^{1}$, Gabriela E. Delpiani ${ }^{2}$, Inés S. Incorvaia ${ }^{3}$, Ana L. Lanfranchi ${ }^{1}$ \\ and Juan T. Timi ${ }^{1}$
}

\author{
${ }^{1}$ Laboratorio de Ictioparasitología, Instituto de Investigaciones Marinas y Costeras (IIMyC-CONICET), Universidad Nacional de \\ Mar del Plata, Mar del Plata, Argentina; \\ ${ }^{2}$ Laboratorio de Ictiología, Instituto de Investigaciones Marinas y Costeras (IIMyC-CONICET), Universidad Nacional de Mar del \\ Plata, Mar del Plata, Argentina; \\ ${ }^{3}$ Instituto Nacional de Investigación y Desarrollo Pesquero (INIDEP), Paseo Victoria Ocampo, Mar del Plata, Argentina; \\ ${ }^{4}$ Comisión de Investigaciones Científicas de la Provincia de Buenos Aires, Argentina
}

\begin{abstract}
A new species of Merizocotyle Cerfontaine, 1894 (Monogenea: Monocotylidae) is described from the nasal tissues of three deep sea rajid skates: the southern thorny skate, Amblyraja doellojuradoi (Pozzi), broadnose skate, Bathyraja brachyurops (Fowler), and yellownose skate, Zearaja chilensis (Guichenot), collected off Buenos Aires Province, Argentina, southwest Atlantic Ocean. Two additional species of sympatric rajid, the white-dotted skate, Bathyraja albomaculata (Norman), and the Patagonian skate, Bathyraja macloviana (Norman), were also examined but no merizocotylines were found. The taxonomy of the Merizocotylinae is not widely accepted and, as a result, the status of Thaumatocotyle and Mycteronastes, and their proposed synonymy with Merizocotyle are currently under discussion. The new species differs from its congeners by having a unique haptoral structure, 6 peripheral loculi that are asymmetrically arranged (one much smaller, indistinctly located in the left or right side of the haptor). The presence of the new species in three sympatric species of Rajidae belonging to distinct genera and subfamilies, as well as its absence in sympatric congenerics indicates the lack of phylogenetic host specificity. Host ecology and geographical distribution appear to be more important than host phylogeny in determining the distribution of this parasite across potential hosts in the region. This constitutes the first record of Merizocotyle in the southwestern Atlantic Ocean.
\end{abstract}

Keywords: taxonomy, monogeneans, host specificity, Amblyraja doellojuradoi, Bathyraja brachyurops, Zearaja chilensis, Argentina

Cerfontaine (1894) proposed Merizocotyle to accommodate $M$. diaphana Cerfontaine, 1894 from Dipturus batis (Linnaeus) (as Raja batis) (Rajidae). Recently, Chisholm and Whittington (2012) described three new species of Merizocotyle. According to these authors, the genus includes 18 species, if Thaumatocotyle Scott, 1904 and Mycteronastes Kearn et Beverley-Burton, 1990, both with different haptoral structure, are junior synonyms of Merizocotyle as proposed by Chisholm and Whittington (1999), based on a previous cladistic analysis of Monocotylidae (Chisholm et al. 1995).

However, other workers consider Thaumatocotyle valid (Neifar et al. 2000, de Buron and Euzet 2005, Marie and Justine 2006, Euzet and de Buron 2010). In fact, a molecular study of Monocotylidae (Chisholm et al. 2001) suggested that Mycteronastes and Thaumatocotyle could constitute valid genera, but indicated that more evidence is required to resurrect them.

Independently of the unsolved phylogeny of these genera of Merizocotylinae Johnston et Tiegs, 1922, members of this subfamily have been recorded worldwide ocean, with the exception of the southwestern Atlantic, where only representatives of Empruthotrema Johnston et Tiegs, 1922 have been reported (Kusnetsova 1975).

Herein, merizocotyline monogeneans were found in the nasal tissue of deep sea skates from the southwest Atlantic Ocean. The specimens are described as a new species of Merizocotyle sensu Chisholm and Whittington (1999).

\section{MATERIALS AND METHODS}

A total of 142 skates were examined: 52 southern thorny skates, Amblyraja doellojuradoi (Pozzi), 14 white-dotted skates, Bathy-

Address for correspondence: M.M. Irigoitia, Laboratorio de Ictioparasitología, Instituto de Investigaciones Marinas y Costeras (IIMyC-CONICET). Universidad Nacional de Mar del Plata, Funes 3350 (7600) Mar del Plata, Argentina. Phone: +54 223 4752426; Fax: +54 223 4753150; E-mail: manuelirigoitia@gmail.com 
raja albomaculata (Norman), 21 broadnose skates, B. brachyurops (Fowler), 22 Patagonian skates, B. macloviana (Norman), and 33 yellownose skates, Zearaja chilensis (Guichenot). Fish were caught off Buenos Aires province by the commercial fleet operating at the Port of Mar del Plata $\left(38^{\circ} 03^{\prime} \mathrm{S}\right.$; $\left.57^{\circ} 32^{\prime} \mathrm{W}\right)$, Argentina, in May 2013. Since samples were obtained from commercial landings, the exact position and depth of catches were unknown, but these species of skates are known to inhabit deep waters at depths under $50 \mathrm{~m}$ isobath (Menni and Stehmann 2000, Cousseau and Perrota 2004, Cousseau et al. 2007).

Fish were necropsied; each olfactory bulb was removed, placed in a Petri dish and examined using a stereoscopic microscope with transmitted light. Monogeneans were collected and washed in saline solution. Some specimens from A. doellojura$d o i$ were studied alive, partially flattened beneath a coverslip, using bright field and differential interference contrast (Nomarski) microscopy. Remaining specimens were fixed in $4 \%$ buffered formaldehyde solution and transferred to $70 \%$ ethanol for storage. Fixed monogeneans were stained with alcoholic chlorhydric carmine, dehydrated in a graded ethanol series, cleared in methyl salicylate and mounted permanently in Canada balsam. A few parasites were cleared in lactic acid to study sclerotised parts (hamuli, marginal hooklets and the male copulatory organ).

Mounted worms were examined and measured using an eyepiece micrometre with light microscopy and drawn with the aid of a drawing tube. All measurements are given in micrometers $(\mu \mathrm{m})$, unless otherwise specified as range with mean in parentheses. The total length was measured excluding the haptor. The male copulatory organ was measured following a straight line from proximal to distal extremes. The egg was measured following a straight line perpendicular to the opercular-filament axis. Morphological terminology follows that of Chisholm et al. (1995). The taxonomy of hosts up to family level is in accordance with Eschmeyer (2013); suprafamily classification follows Nelson (2006), unless otherwise indicated.

Type material was deposited in the Helminthological Collection of the Museo de La Plata, La Plata, Argentina (HCMLP), and in the Helminthological Collection of the Institute of Parasitology, Biology Centre, Academy of Sciences of the Czech Republic, České Budějovice, Czech Republic (IPCAS).

To test whether the specimens recovered from different host species were conspecific, we performed a one-way non-parametric permutation-based multivariate analysis of variance (PERMANOVA). Twenty-two of the monogeneans collected (including 10 worms from A. doellojuradoi, 6 from B. brachyurops and 6 from $Z$. chilensis) were in good condition and allowed measuring all relevant structures. For each worm, 20 morphometric variables were recorded when possible (Table 1). Following Anderson et al. (2008), a permutation of residuals under a reduced model was used as the method of permutation. A sequential sum of squares (Type I SS) was applied because total length of worms was introduced as a covariable (ANCOVA model) to eliminate the effect of differential size on comparisons. Since PERMANOVA is sensitive to differences in multivariate dispersions between groups, these differences, measured as distances to the centroids, were compared using the PERMDISP routine (Anderson et al. 2008).

PERMANOVA and PERMDISP analyses were conducted with the software PERMANOVA + for PRIMER (Anderson et al. 2008), based on a resemblance matrix of Euclidean distance.
A previous square-root transformation was carried out and significance values were based on 9999 permutations.

\section{RESULTS}

A total of 48 monogeneans infected three host species, including Bathyraja brachyurops (prevalence 33\%, mean intensity 1.6), Zearaja chilensis (prevalence 23\%, mean intensity 1.8), and Amblyraja doellojuradoi (prevalence $15 \%$, mean intensity 1.8 ). No parasites were found on the nasal tissue of Bathyraja albomaculata and Bathyraja macloviana.

\section{Merizocotyle euzeti $\mathrm{sp} . \mathrm{n}$.}

Figs. 1-7

Description (based on 22 whole-mounts, measurements for each host species are given in Table 1).

Body 1.6-3.6 mm (2.6 mm, $\mathrm{n}=22)$ long, dorsoventrally flattened, elongated and narrow, with maximum width 310-1 $170(615, \mathrm{n}=22)$ at level of testis (Fig. 1). Anterior end of body with slight indentation and 3 anterolateral gland-duct openings on each side of ventrolateral margin (Fig. 1). Anterior glands scattered throughout head region. Posterior end of body rounded. Eyespots or dispersed pigment granules absent. Tegument smooth.

Haptor oval, 550-910 (703, $\mathrm{n}=22)$ long, 450-960 $(648, \mathrm{n}=22)$ wide, arising from short peduncle at posterior end of body, with ventral surface divided into 1 central loculus, 6 asymmetrically arranged peripheral loculi (one much smaller, indistinctly located in left or right side of haptor) and 18 marginal loculi, posteriormost being largest (Figs. 1, 2). Haptor armed with 1 pair of hamuli, 180-300 (244, $\mathrm{n}=21)$ long (Fig. 3) and 14 marginal hooklets, 19-24 $(23, \mathrm{n}=22)$ long (Fig. 4), distributed as illustrated in Fig. 2.

Mouth ventral, at level of anterior portion of pharynx. Pharynx muscular, bulbous, 200-375 $(279, \mathrm{n}=22)$ long, 138-268 $(199, \mathrm{n}=22)$ wide. Two intestinal caeca (partially covered by vitellarium) unbranched, on each side of body, extending posteriorly approximately parallel to lateral body margin, not confluent posteriorly; caecal bifurcation immediately posterior to pharynx.

Testis single, 410-1240 (783, $\mathrm{n}=20)$ long, maximum width $140-700(323, \mathrm{n}=20)$, occupying intercaecal space from middle of body to just anterior to posterior end of vitellarium (Fig. 1). Vas deferens arising medially from anterior portion of testis and running anteriorly, dorsal to transverse vitelline duct where it widens to form seminal vesicle (Fig. 1). Seminal vesicle running anteriorly, bending dextral at level of common genital pore, then turning to sinistral side and extending forward to level of pharynx where it returns to join ejaculatory bulb (Fig. 1). Ejaculatory bulb thin-walled, with two distinct spherical internal chambers, dorsal to male copulatory organ. Male copulatory organ $130-193(160, \mathrm{n}=22)$ long, 5-7 $(6, \mathrm{n}=22)$ wide, straight, narrow, sclerotised tube, coiled distally (Fig. 5). Accessory piece absent. 
Table 1. Comparative measurements (in $\mu \mathrm{m}$ unless otherwise stated as the mean followed by the range and number of specimens measured in parentheses) of specimens of Merizocotyle euzeti sp. n. from three skate species from the Argentine Sea.

\begin{tabular}{llll}
\hline & Amblyraja doellojuradoi & Bathyraja brachyurops & Zearaja chilensis \\
\hline Body length (BL) (mm)* & $2.6(1.8-3.6, \mathrm{n}=10)$ & $2.6(1.6-3.0, \mathrm{n}=6)$ & $2.4(1.9-3.2, \mathrm{n}=6)$ \\
Body maximum width* & $664(440-1170, \mathrm{n}=10)$ & $616(450-820, \mathrm{n}=6)$ & $530(310-810, \mathrm{n}=6)$ \\
Haptor length (HL)* & $749(590-910, \mathrm{n}=10)$ & $687(570-780, \mathrm{n}=6)$ & $642(550-770, \mathrm{n}=6)$ \\
Haptor width* & $704(540-960, \mathrm{n}=10)$ & $624(560-710, \mathrm{n}=6)$ & $577(450-740, \mathrm{n}=6)$ \\
Hamuli length* & $240(180-300, \mathrm{n}=10)$ & $244(218-268, \mathrm{n}=6)$ & $252(235-268, \mathrm{n}=5)$ \\
Hooklet length* & $23(22-24, \mathrm{n}=10)$ & $23(22-24, \mathrm{n}=6)$ & $22(19-24, \mathrm{n}=6)$ \\
Pharynx length* & $298(225-375, \mathrm{n}=10)$ & $265(200-315, \mathrm{n}=6)$ & $259(213-320, \mathrm{n}=6)$ \\
Pharynx width* & $216(163-268, \mathrm{n}=10)$ & $185(138-225, \mathrm{n}=6)$ & $186(153-245, \mathrm{n}=6)$ \\
MCO length* & $163(130-193, \mathrm{n}=10)$ & $163(150-175, \mathrm{n}=6)$ & $152(145-163, \mathrm{n}=6)$ \\
MCO maximum width* & $6(5-7, \mathrm{n}=10)$ & $6(6-7, \mathrm{n}=6)$ & $6(\mathrm{n}=6)$ \\
Ootype length* & $397(255-663, \mathrm{n}=8)$ & $320(228-383, \mathrm{n}=6)$ & $392(375-425, \mathrm{n}=3)$ \\
Egg size & $170(158-193, \mathrm{n}=3)$ & $162(\mathrm{n}=1)$ & - \\
Testis length* & $764(430-1240, \mathrm{n}=8)$ & $908(460-1100, \mathrm{n}=6)$ & $682(410-1090, \mathrm{n}=6)$ \\
Testis maximum width* & $310(170-700, \mathrm{n}=8)$ & $368(220-570, \mathrm{n}=6)$ & $295(140-470, \mathrm{n}=6)$ \\
Anterior end to mouth* & $303(240-370, \mathrm{n}=9)$ & $352(220-420, \mathrm{n}=6)$ & $335(240-450, \mathrm{n}=6)$ \\
Anterior end to CGP* & $905(640-1180, \mathrm{n}=8)$ & $933(660-1040, \mathrm{n}=6)$ & $923(710-1210, \mathrm{n}=6)$ \\
Anterior end to VP* & $993(695-1260, \mathrm{n}=8)$ & $967(658-1110, \mathrm{n}=6)$ & $909(730-1163, \mathrm{n}=6)$ \\
Anterior end to anterior end of vitellarium* & $511(400-600, \mathrm{n}=9)$ & $517(350-590, \mathrm{n}=6)$ & $505(400-640, \mathrm{n}=6)$ \\
Posterior end to posterior end of vitellarium* $295(200-390, \mathrm{n}=8)$ & $377(250-470, \mathrm{n}=6)$ & $343(300-400, \mathrm{n}=6)$ \\
Vitellarium length (VL)* & $1743(1070-2500, \mathrm{n}=8)$ & $1748(970-1970, \mathrm{n}=6)$ & $1550(1120-2120, \mathrm{n}=6)$ \\
Anterior end to TVD* & $1064(790-1340, \mathrm{n}=9)$ & $1088(770-1240, \mathrm{n}=6)$ & $1082(830-1330, \mathrm{n}=6)$ \\
\% HL: BL & $29(24-38, \mathrm{n}=10)$ & $27(22-36, \mathrm{n}=6)$ & $27(24-30, \mathrm{n}=6)$ \\
\% VL: BL & $68(58-78, \mathrm{n}=8)$ & $66(62-68, \mathrm{n}=6)$ & $64(58-70, \mathrm{n}=6)$
\end{tabular}

* measurements used in the multivariate analysis; CGP - common genital pore; MCO - male copulatory organ; TVD - transverse vitelline duct; $\mathrm{VP}$ - vaginal pore

Blind end of ovary not lobed, dorsal to testis. Ovary looping right intestinal caecum dorsoventrally, then turning to anterior region just slightly anterior to common vitelline duct, where it runs posteriorly and narrows to form oviduct (Fig. 7). Oviduct joining both common vitelline duct and seminal receptacle, then connecting to ootype (Fig. 7). Vaginal pores opening ventrolateral at level of, or immediately posterior to, common genital pore (Figs. 1, 7). Two vaginae, lacking sclerotised walls, muscular, extending posteriorly, fusing at midline to join seminal receptacle (Figs. 1,7). Common vaginal duct partially seen. Junction of seminal receptacle with ovovitelline duct seen in only one specimen.

Dense vitellarium, 970-2500 $(1687, \mathrm{n}=20)$ long, in extracaecal position, not confluent anteriorly nor posteriorly, consisting of vitelline ducts and vitelline cells, and extending from level of pharynx to posterior portion of body (Fig. 1). Transverse vitelline duct immediately posterior to vaginae, dorsal to seminal receptacle, common vitelline duct partially seen. Mehlis' gland located between testis and transverse vitelline ducts connecting to descending limb of ootype (Figs. 1, 7). Ootype muscular, 228-663 $(369, \mathrm{n}=17)$ long, leading to common genital pore anteriorly. Descending and ascending limbs of ootype present (Figs. 1, 7). Egg tetrahedral, 158-193 $(168, n=4)$ long, with operculum and large filament on opposite poles (Fig. 6).

Type host: Bathyraja brachyurops (Fowler) (Rajiformes: Rajidae).
Ot he r hosts: Amblyraja doellojuradoi (Pozzi) (Rajiformes: Rajidae) and Zearaja chilensis (Guichenot) (Rajiformes: Rajidae).

Type locality: Deep waters off Buenos Aires Province, Argentina.

Site of infection: Nasal tissues.

Material deposited: Holotype HCMLP MLP-He No 6727 , and 10 paratypes, 8 of them deposited in the HCMLP (MLP-He No 6728) and other 2 in the Institute of Parasitology, České Budějovice, Czech Republic (IPCAS M-550).

Etymology: The new species is named in memoriam of Louis Euzet for his invaluable contribution to the knowledge of Monogenea.

Differential diagnosis: The new species can be readily distinguished from all previously described species by the presence of 6 peripheral loculi asymmetrically distributed in the haptor. This constitutes a new haptor type which we term 'Type 6', following Chisholm and Whittington (1999). If we discount the differences in peripheral loculus number, Merizocotyle euzeti sp. $\mathrm{n}$. is most similar to M. amplidiscata Dillon et Hargis, 1965, M. diaphana, M. pugetensis Kay, 1942, and M. sinensis Timofeeva, 1984, which are all members of Merizocotyle sensu stricto (s.s.), as defined by Chisholm and Whittington (1995).

These species all have a large testis, which occupies a considerable proportion of body length, and an ootype with ascending and descending limbs (Cerfontaine 1894, Kay 1942, Dillon and Hargis 1965, Timofeeva 1984). The 
1

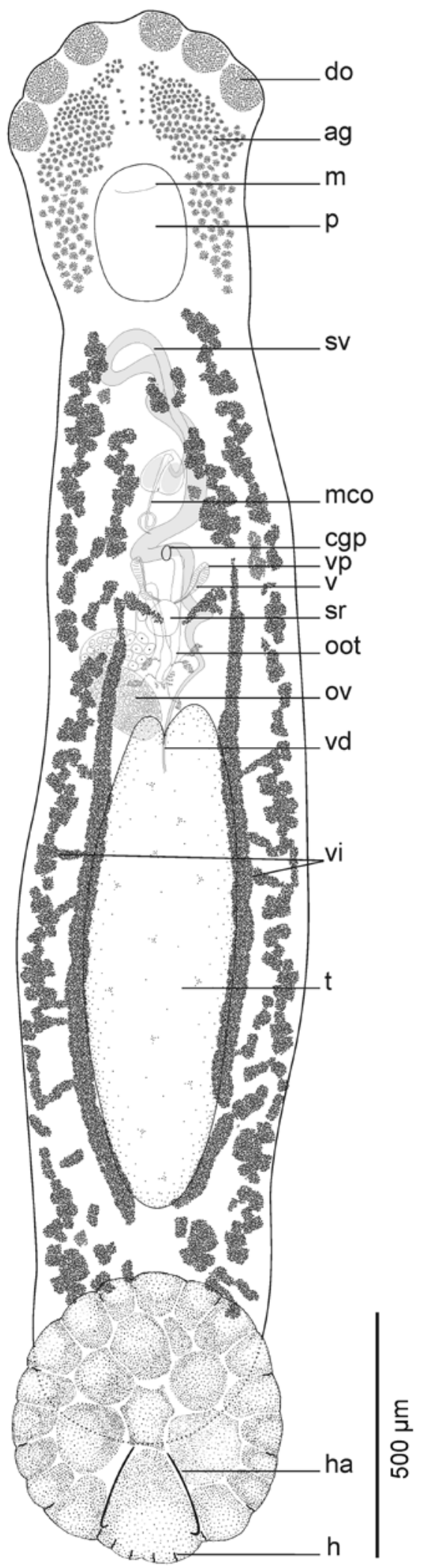

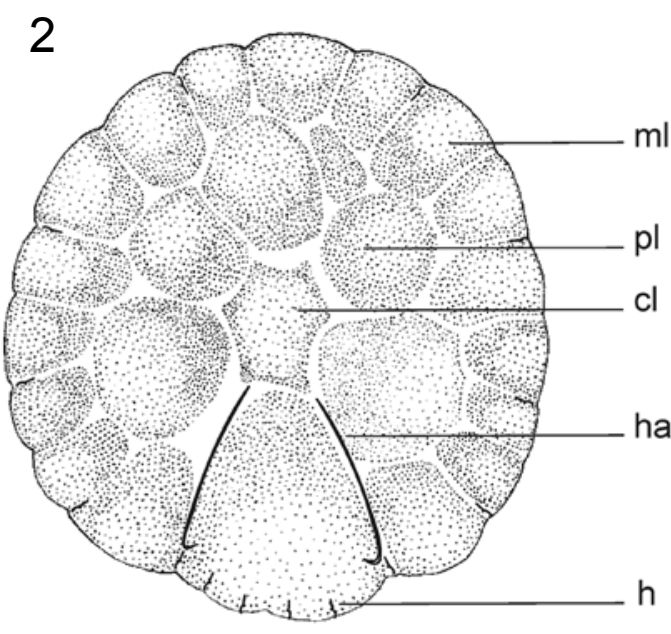

|틀

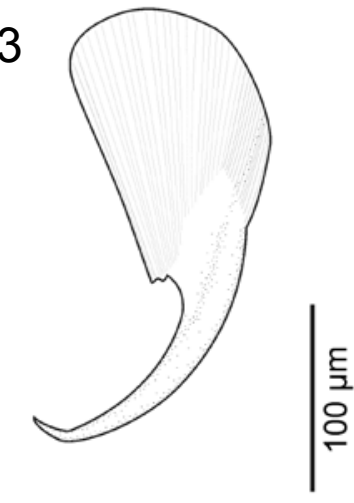

4

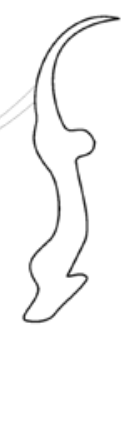

5

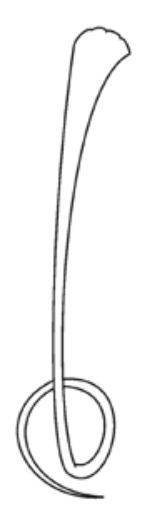

6

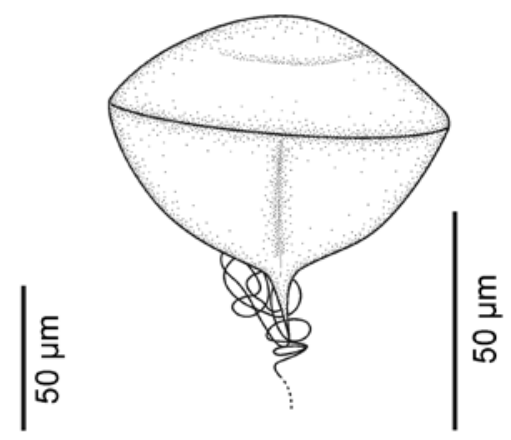

Figs. 1-6. Merizocotyle euzeti sp. n. Fig. 1. Whole-mounted specimen, ventral view, composite drawing. Fig. 2. Haptor. Fig. 3. Hamulus. Fig. 4. Hooklet. Fig. 5. Male copulatory organ. Fig. 6. Egg. Abbreviations: ag - anterior gland; cgp - common genital pore; $\mathrm{cl}$ - central loculus; do - anterior gland duct opening; $\mathrm{h}$ - hooklet; ha - hamulus; $\mathrm{m}$ - mouth; mco - male copulatory organ; $\mathrm{ml}$ - marginal loculus; oot - ootype; ov - ovary; $\mathrm{p}$ - pharynx; $\mathrm{pl}$ - peripheral loculus; $\mathrm{sr}$ - seminal receptacle; $\mathrm{sv}$ - seminal vesicle; $\mathrm{t}$ - testis; $\mathrm{v}$ - vagina; vd - vas deferens; vi - vitellarium; vp - vaginal pore. 


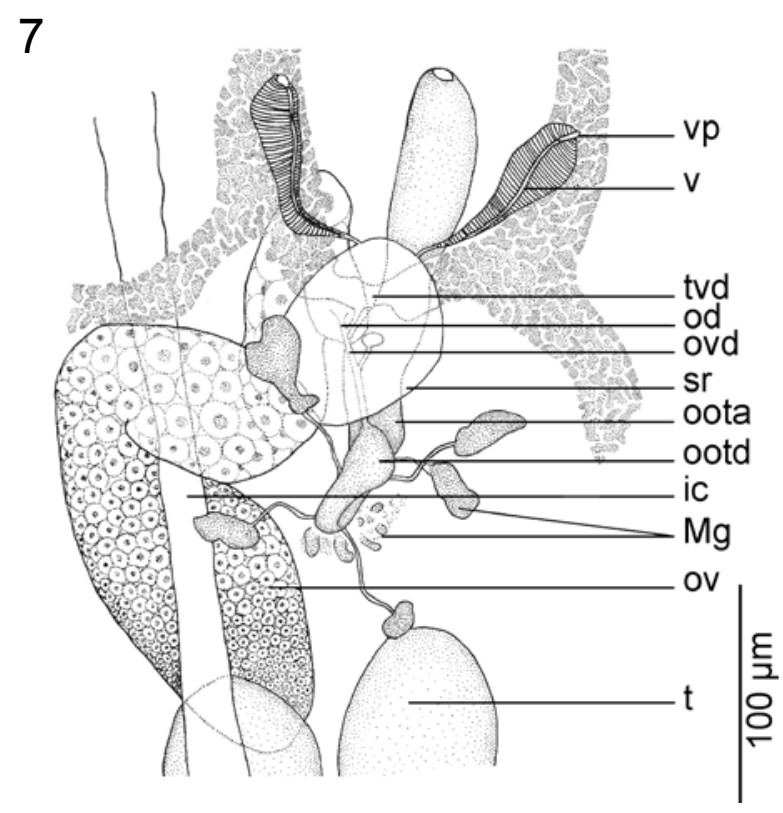

Fig 7. Details of female reproductive system of Merizocotyle euzeti sp. n. Abbreviations: ic - intestinal caecum; $\mathrm{Mg}$ - Mehlis' gland; od - oviduct; oota - ootype ascending limb; ootd - ootype descending limb; ov - ovary; ovd - ovovitellin duct; sr - seminal receptacle; $\mathrm{t}$ - testis; tvd - transverse vitelline duct; $\mathrm{v}$ - vagina; $\mathrm{vp}$ - vaginal pore.

presence of an asymmetrical peripheral loculus and the absence of eyespots, however, are features that distinguish the new species from $M$. sinensis, but that are shared with the three last species (Timofeeva 1984, Chisholm and Whittington 1999). Moreover, a loop is present at the distal end of the copulatory organ of $M$. amplidiscata, M. euzeti sp. n. and M. pugetensis.

Unfortunately, the morphology of the male copulatory organ was not clearly illustrated nor described for M. diaphana by Cerfontaine $(1894,1898)$ and, therefore, no comparisons can be made. It has been suggested that M. amplidiscata, $M$. diaphana and $M$. pugetensis may be conspecific because differences in the size of sclerotised structures are not good characters to separate species of Merizocotyle, due to intraspecific variability (Chisholm and Whittington 1999).

\section{Multivariate Analysis}

PERMANOVA results showed no differences among multivariate data of morphometric measurements of specimens found in the three species of skates (Pseudo $F=1.44, P($ perm $)=0.12$; PERMDISP: $F=0.99$, $P($ perm $)=0.44)$.

\section{DISCUSSION}

The taxonomic history of Merizocotyle has been complicated since its proposal by Cerfontaine (1894), with numerous synonymies not only among species, but also among genera, such as Pseudomerizocotyle Kay, 1942,
Thaumatocotyle and Mycteronastes (see Chisholm and Whittington 1999 for taxonomic history).

The systematics of the Merizocotylinae changed considerably after a morphology-based phylogenetic analysis of Monocotylidae carried out by Chisholm et al. (1995). The authors stated that they failed to demonstrate synapomorphies for Merizocotyle s.s. and Mycteronastes, considering the number of marginal loculi as plesiomorphic and the number of peripheral loculi as non-informative, both characters being the basis of previous discriminations between genera. Therefore, Chisholm et al. (1995) synonymized Mycteronastes with Merizocotyle, and, although Thaumatocotyle formed a monophyletic group, its was also synonymised because, according to the authors, its recognition would render Merizocotyle paraphyletic. Consequently Merizocotyle was redefined, containing 11 species.

This classification was later retained by Chisholm and Whittington (1999) in their revision of Merizocotylinae, who defined 5 types of haptor in Merizocotyle: Type 1 with 1 central loculus, 7 peripheral and 21 marginal loculi; Type 2 with 1, 7 and 18; Type 3 with 1, 5 and 18; Type 4 with 1, 4 and 12; and Type 5 with 1, 4 and 13. Species with haptor Type 1 (M. sinensis) and Type 2 (M. amplidiscata, M. diaphana and M. pugetensis) are considered Merizocotyle s.s. by Chisholm and Whittington (1999); those with haptor Type 3 (M. icopae Beverley-Burton et Williams, 1989 and M. undulatae (Kearn et BeverleyBurton, 1990)) were previously members of Mycteronastes; the Type 4 is unique to $M$. urolophi Chisholm et Whittington, 1999; and Type 5 includes those species transferred from Thaumatocotyle, namely M. australensis (Beverley-Burton et Williams, 1989), M. concinna (Scott, 1904), M. dasybatis MacCallum, 1916, M. longicirrus (Hargis, 1955) and M. pseudodasybatis (Hargis, 1955).

The classification of Chisholm et al. (1995) was not accepted by Neifar et al. (2000) who recognized Thaumatocotyle when they described the new species, T. tunisiensis Neifar, Euzet et Hassine, 2000. These authors considered that the number of marginal and peripheral loculi were valid diagnostic features to distinguish this genus from Merizocotyle, as previously used by Price (1938), Sproston (1946) and Beverley-Burton and Williams (1989); however, they did not make reference to the validity of Mycteronastes.

Later, Chisholm et al. (2001) re-evaluated the morphological phylogeny of the Monocotylidae proposed by Chisholm et al. (1995) based on molecular analyses of $28 \mathrm{~S}$ ribosomal DNA sequences. Their analysis included sequence data of M. icopae (Type 3, formerly in Mycteronastes), M. australensis (Type 5, formerly in Thaumatocotyle) and M. urolophi (Type 4); the latter was not included in the previous morphological phylogeny. The molecular results suggested that Mycteronastes and Thaumatocotyle should be resurrected and that M. urolophi 
could represent a distinct genus. However, Chisholm et al. (2001) argued that sequences of more species need to be analysed, particularly those of the Merizocotyle s.s. group, before making these nomenclatural decisions.

In spite of the results of Neifar et al. (2000) and Chisholm et al. (2001), there has not been consensus as to the validity of Thaumatocotyle, as reflected in later publications, where additional species have been referred to as either Thaumatocotyle - de Buron and Euzet (2005), Marie and Justine (2006), Euzet and de Buron (2010) or Merizocotyle - Chisholm and Whittington (2012).

Despite questions on the validity of Thaumatocotyle and Mycteronastes, or their synonymy with Merizocotyle, the number and distribution of the peripheral haptoral loculi do allow us to differentiate the new species from described members of Merizocotyle sensu Chisholm and Whittington (1999).

In contrast, the host taxonomy supports a closer relationship between $M$. euzeti sp. n. and species of Merizocotyle s.s., namely $M$. amplidiscata, M. diaphana and M. pugetensis. In fact, all of these species, plus M. undulatae (formerly in Mycteronastes) infect species of Rajidae (Rajiformes), whereas M. icopae (formerly in Mycteronastes), and M. sinensis parasitize species of Rhinobatidae (Rajiformes). All other nominal species of Merizocotyle sensu lato mainly infect species of Dasyatidae (Myliobatiformes).

As pointed out by Chisholm et al. (2001), future studies including additional molecular data from other merizocotylines, especially from species of Merizocotyle s.s., will help clarify systematics of Merizocotyle sensu lato, and of the new species particularly. Distribution of haptoral loculi and internal morphology could provide key evidence for solving the confusing classification of the group and defining the systematic value of these characters at the generic level.

Herein, we report the same monocotylid from three sympatric species of Rajidae that are each assigned to distinct genera and subfamilies (McEachran and Aschliman 2004). This indicates that the new species cannot be considered as strictly host specific. In contrast, its absence in the sympatric congenerics Bathyraja albomaculata and B. macloviana indicates that processes other than host phylogeny determine the distribution of this parasite across potential hosts in the region. Its specificity is probably related to still unknown particular ecological traits shared by its host species.

Further studies including a greater number of hosts and samples, a broader geographical coverage and additional species of Rajidae and related families will help disentangle to what extent phylogenetic relatedness of hosts is important in determining the degree of parasite sharing among skates, as well as the influence of host ecology and geographical distribution in such specificity patterns.

Acknowledgements. Thanks are extended to Miguel Fitipaldi and Atilio Altamiranda from El Corsario, Ana Massa and the team of the Programa de Condrictios (INIDEP) for providing fish samples, to M.A. Rossin (Lab. Ictioparasitología, IIMyC) for helping with fish sampling, Leslie A. Chisholm (Monogenean Research Laboratory, Parasitology Section, South Australian Museum, Australia) for kindly providing some literature. Special thanks are due to the two anonymous referees for their valuable comments that helped to improve this article. Financial support was provided by grants from CONICET (PIP No. 112201101-00036); ANPCyT (PICT No. 2012-2094) and Universidad Nacional de Mar del Plata (EXA 621/12). This work is part of the doctoral thesis of M.M.I. carried out in the Universidad Nacional de Mar del Plata, Facultad de Ciencias Exactas y Naturales.

\section{REFERENCES}

Anderson M.J., Gorley R.N., Clarke K.R. 2008: PeRMAnOVA for PRIMER: Guide to Statistical Methods. PRIMER-E, Plymouth, $240 \mathrm{pp}$.

Beverley-Burton M., Williams A. 1989: Merizocotyle icopae, sp. nov., and Thaumatocotyle australensis, sp. nov. (Monogenea: Monocotylidae) from the nasal cavities of rajiform elasmobranchs from the Great Barrier Reef. Aust. J. Zool. 37: 25-35.

de Buron I., Euzet L. 2005: A new species of Thaumatocotyle (Monogenea: Monocotylidae) from Dasyatis sabina (Myliobatiformes: Dasyatidae) off the coast of South Carolina. J. Parasitol. 91: 791-793.

Cerfontaine P. 1894: Note sur un nouveau tristomien Merizocotyle diaphanum (n. g., n, sp.). Bull. Acad. Roy. Belg. 27: 936-948.

Cerfontaine P. 1898: Le genre Merizocotyle (Cerf.). Arch. Biol. 15: 329-366.

Chisholm L.A., Morgan J.A.T., Adlard R.D., Whittington I.D. 2001: Phylogenetic analysis of the Monocotylidae (Monogenea) inferred from 28S rDNA sequences. Int. J. Parasitol. 31: 1537-1547.
Chisholm L.A., Wheeler T.A., Beverley-Burton M. 1995: A phylogenetic analysis and revised classification of the Monocotylidae Taschenberg, 1879 (Monogenea). Syst. Parasitol. 32: 159-191.

Chisholm L.A., Whittington I.D. 1999: A revision of the Merizocotylinae Johnston and Tiegs, 1922 (Monogenea: Monocotylidae) with descriptions of new species of Empruthotrema Johnston and Tiegs, 1922 and Merizocotyle Cerfontaine, 1894. J. Nat. Hist. 33: 1-28.

Chisholm L.A., Whittington I.D. 2012: Three new species of Merizocotyle Cerfontaine, 1894 (Monogenea: Monocotylidae) from the nasal tissues of dasyatid rays collected off Malaysian and Indonesian Borneo. Syst. Parasitol. 82: 167-176.

Cousseau M.B., Figueroa D.E., Díaz de Astarloa J.M., Mabragaña E., Lucifora L.O. 2007: Rayas, Chuchos y Otros Batoideos del Atlántico Sudoccidental $\left(34^{\circ} \mathrm{S}-55^{\circ} \mathrm{S}\right)$. Publicaciones Especiales INIDEP, Mar del Plata, 102 pp.

Cousseau M.B., Perrota R. 2004: Peces Marinos de Argentina. Biología, Distribución, Pesca. Publicaciones Especiales INIDEP, Mar del Plata, 167 pp. 
Dillon W.A., Hargis W.J. 1965: Monogenetic trematodes from the southern Pacific Ocean. 1. Monopisthocotylids from New Zealand fishes. [Biology of the Antarctic Seas II.], Antarct. Res. Ser. 5: 229-249.

Eschmeyer, W. N. (Ed.) 2013: Genera, Species, References. World Wide Web electronic publication, http://research.calacademy.org/research/ichthyology/catalog/fishcatmain.asp, $10 / 2013$.

Euzet L., DE Buron I. 2010: Thaumatocotyle (Monogenea: Monocotylidae) from Dasyatidae (Elasmobranchii) of the North American Atlantic coast: current issues resolved. J. Parasitol. 96: 1010-1013.

KaY M.W. 1942: Notes on the genus Merizocotyle Cerfontaine with a description of a new species. Trans. Am. Microsc. Soc. 61: $254-260$

KuZnetsova I.G. 1975: [Monogenea from Chondrichthyes fish of the Patagonian Shelf.] Ekologicheskaya i Eksperimental'naya Parazitologiya 1: 143-153. (In Russian.)

Marie A.D., Justine J.-L. 2006: Thaumatocotyle pseudodasybatis Hargis, 1955 (Monogenea: Monocotylidae) from Aetobatus cf. narinari, with a comparison of specimens from Australia, French Polynesia and New Caledonia. Syst. Parasitol. 64: 4755 .

Received 15 October 2013
McEachran J.D, and Aschliman A.D., 2004: Phylogeny of Batoidea. In: J. Carrier, J. Musick and M. Heithaus (Eds.), Biology of Sharks and Theirs Relatives. CRC Press Boca Raton, Florida, pp. 1-376.

Menni R.C., Stehmann, M.F.W. 2000: Distribution, environment and biology of batoid fishes off Argentina, Uruguay and Brazil. A review. Rev. Mus. Arg. Cs. Nat. 2: 69-109.

Neifar L., Euzet L., Ben Hassine O.K. 2000: New species of the Monocotylidae (Monogenea) from the stingray Dasyatis tortonesi Capapé (Euselachii, Dasyatidae) off the Tunisian coast, with comments on host-specificity and the specific identities of Mediterranean stingrays. Syst. Parasitol. 47: 43-50.

Nelson J.S. 2006: Fishes of the World. John Wiley \& Sons, Inc. 4th Edition, New Jersey, $601 \mathrm{pp}$.

Price E.W. 1938: North American monogenetic trematodes. II. The families Monocotylidae, Microbothriidae, Acanthocotylidae and Udonellidae (Capsaloidea). J. Wash. Acad. Sci. 28: $183-198$.

Sproston N.G. 1946: A synopsis of the monogenetic trematodes. Trans. Zool. Soc. Lond. 25: 185-600.

TimofeEva T.A. 1984: [New members of monocotylids of the genera Monocotyle and Merizocotyle from rays of the South Chinese and Yellow Seas (Monogenea, Monocotylidae).] Parazitologiya 18: 296-305. (In Russian.)

Accepted 19 December 2013 